\section{Validation of an Instrument to Assess the Skill Levels of Adolescent Students to Learn Knowledge}

\author{
Marco Cossio-Bolaños ${ }^{a, b,{ }^{*}}$ Cynthia Lee Andruske ${ }^{b}$, Rodrigo Vargas \\ Vitoriaa $^{\text {, Juan Lagos Luciano }}{ }^{c}$, Cristian Luarte-Rochad, \\ Jose Sulla-Torres ${ }^{\mathrm{e}}$, Rossana Gómez-Campos ${ }^{\text {, * }}$
}

\begin{tabular}{ll}
\hline Received: & 27 March 2019 \\
Revised: $\quad$ 02 July 2019 \\
Accepted: $\quad$ 03 September 2019 \\
ISSN: 1307-9298 \\
Copyright (C) IEJEE \\
www.iejee.com
\end{tabular}

DOI: 10.26822/iejee.2019155336

\begin{abstract}
The objectives of this study were to a) verify the validity and reliability of a scale to assess skill levels to learn content knowledge (SLACK) and b) develop percentile norms to assess the SLACK of adolescent students. The study included 2270 students (1134 males and 1136 females) ranging in age from 10.0 to 18.9 years old. A scale was used to measure the SLACK. The results showed high values of validity (saturation between .32 and .54) and with internal consistency from .83 and .84. The LMS method made it possible to create percentiles p10, p50, and p90 in order to classify the (SLACK) based on category, age, and sex. The results suggested the use and application of the scale with the school education system by using the percentiles to diagnosis, classify, and monitor the skills for learning knowledge validly and reliably.
\end{abstract}

Keywords: Competencies, Learning, Validity, Reliability, Percentiles.

\section{Introduction}

The skill for learning refers to acquisition, selection, and integrated mobilization of knowledge, skills, and attitudes necessary to learn continuously throughout the lifetime (Villardón-Gallego, Yániz, Achurra, Iraurgi, \& Aguilar, 2013). This process is based on experiences and previous learning. The objective of these is to use and apply new knowledge and capabilities in diverse contexts, such as those from private and professional life as well as those during education and formation, respectively (CCE, 2005).

All learning activities undertaken throughout life are done so with the objective to improve knowledge, skills, and competencies (European Commission, 2001). In this sense, the school's agenda, among other goals, is the need to teach to learn. This is to provide to students the individual and interpersonal resources that permit them to confront challenges with autonomy, activating their knowledge, abilities, and ability to solve problems successfully (IVEIE, 2012, p 4).

In general, self-directed learning can be defined as the degree students participate actively in their own learning processes from a meta-cognitively, motivationally, and behaviorally (Zimmerman, 1989). Therefore, the success of the competency translates into the mobilization of all of the resources the individual has access to effectively resolve a particular demand, situation, or problem (Rios \& Gómez, 2013).

Based on this perspective, a number of recent studies have focused their objectives on studying dimensions and/or categories of skills for learning (Cabanach et al., 2006; Sáiz, Montero, Bol, \& Carbonero, 2012; Suárez \& Fernández, 2011; Villardón-Gallego, Yániz, Achurra, Iraurgi, \& Aguilar, 2013) where self-efficacy, self-directed, and cognitive and affective strategies stand out, including the construction and transfer of knowledge, among other dimensions.
In fact, these proposals developed for schools and universities play a fundamental role when it is time to measure skills for learning. Therefore, with these instruments, it is possible to diagnose, classify, and monitor students during school and university years. However, to date, no research studies exist that demonstrate scales or instrument that allow diagnosis and classification of skills for learning knowledge at the student level. In addition, actually, Chile has no valid and/or adapted instruments to assess the youth and adolescent student population. Studying this problem is relevant in terms of incorporating new knowledge. Competencies for learning are composed of different elements that favor effective performance throughout life (Villardón-Gallego et al., 2013). Above all, these are needed for different learning contexts that arise (Salmerón \& Gutiérrez, 2012) inside and outside school programs.

From this perspective, the objectives of this study were a) to verify the validity and reliability of an instrument that assesses the skill levels of adolescent students to learn and b) to develop percentile norms to validate the skill levels for learning in adolescent students. This information may be useful for multi-disciplinary educational professionals since the use and application of this instrument may help students acquire new knowledge in particular areas of the life sciences.

\section{Methodology}

Sample

A descriptive cross-sectional project was designed to study 2270 adolescents (1134 males and 1136 females) in the Maule Region (Chile). Students were selected probabilistically (stratified by proportional allocation), representing $14 \%$ of the total population $\%(\mathrm{Cl}=95 \%)$. The calculation procedure is depicted in Figure 1. Age ranged from 10.0 to 18.9 years. The average age for both sexes was $14.23 \pm 2.39$. Six munici-

\footnotetext{
*Corresponding Author: Rossana Gómez-Campos, Department of Diversity and Educational Inclusivity, Catholic University of Maule

E-mail: rossaunicamp@gmail.com

a Department of Physical Activity Sciences of the Catholic University of Maule, Talca, Chile.

${ }^{b}$ Centro de Investigación CINEMAROS, Arequipa, Perú

cDepartment of Diversity and Educational Inclusivity. Catholic University of Maule, Talca, Chile

Universidad San Sebastián, Concepción, Chile

eUniversidad Nacional de San Agustín, Arequipa, Perú
} 
pal schools located in the urban area of the Maule Region (Chile) were included in this study.

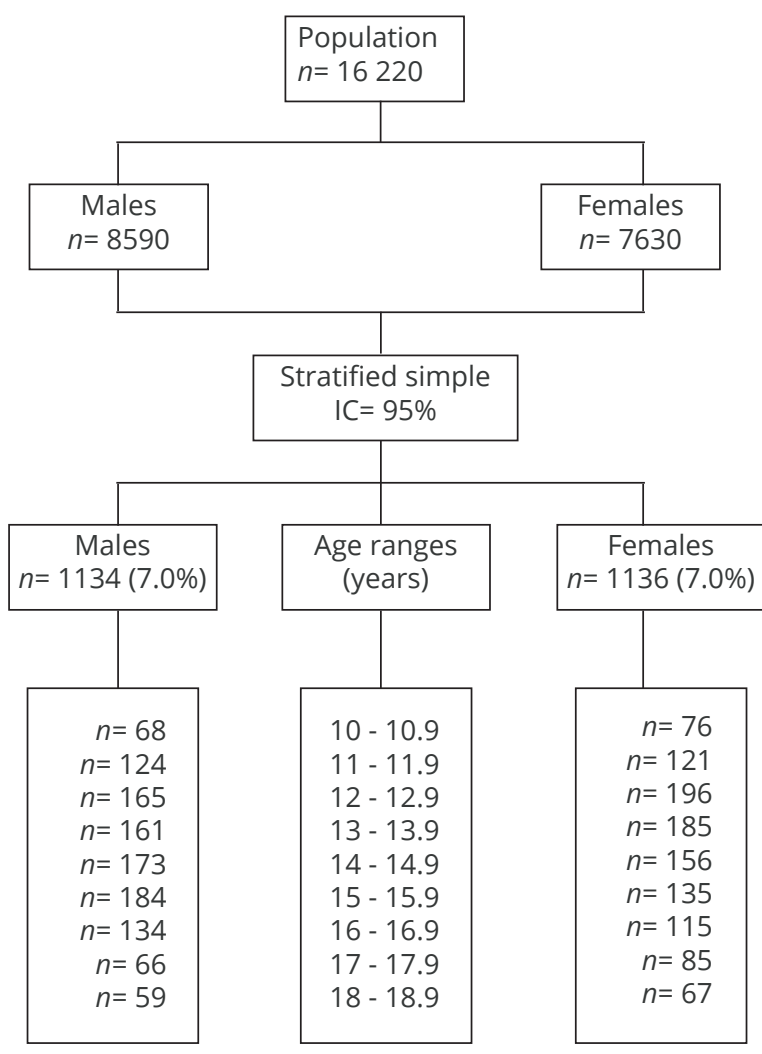

Figure 1. Selection procedure for the sample $(n=2270)$.

Students selected to participate in the study were those attending classes regularly at each of the schools and providing written informed consent. Students not attending the daily evaluations, not completing the information on the questionnaire, or not providing informed consent were excluded from the study. The research was based on the Declaration of Helsinki and the ethical procedures of the local Ethics Committee.

\section{Techniques and Instruments}

To collect information about competencies for learning, a questionnaire was used as the data collection instrument. It was originally proposed by Villardón-Gallego et al. (2013). This questionnaire is composed of four categories and/or indicators (knowledge transfer, personal knowledge about how to learn, knowledge construction, and self-directed learning). The questionnaire consists of a total of 18 questions. The validity of the original instrument was determined by using three techniques: a panel of experts, confirmatory factorial analysis CFA (RMSEA $=.039$ ), and criterion validity $(r=.72)$.

The instrument was given during the school day (8:00 to 12:00 hours) Monday to Friday based on school timetables, availability, and permission. A team of examiners was in charge of the procedures for giving the questionnaire. The four examiners had previously undergone training for procedures for collecting information in the schools selected for the research study. At the beginning of the testing procedures, the objectives and the relevance of the study were explained. Afterwards, instructions were provided about how to fill out the questionnaire. Between 10-15 minutes were given for students to complete the necessary information. While filling out the questionnaire, students could request additional information if they had questions about the questionnaire. The questionnaire was given only once to the students. The instrument provided three alternative answers:
a) always,
b) sometimes, and
c) never.

To validate the instrument, construct validity was chosen (confirmatory analysis). The original questionnaire instrument consisted of 18 questions. However, after validating the instrument, two questions were eliminated (numbers 6 and 12 from the original version). The questions eliminated showed communalities less than .30 and Cronbach's $a<a$.70. As a result, the instrument was reduced to 16 question items for the Chilean version. Reliability was determined by the technique of internal consistency $(r=.86)$. To evaluate the skill level for learning, percentiles were used. The cut-off points adopted were $<$ p10 for the low level, p10 to p90 for the moderate level, and > p90 for the high level.

\section{Statistical Procedures}

Previously, normality of the data was verified by means of the Kolmogorov-Smirnov method. Subsequently, descriptive analysis of the arithmetic mean, standard deviation, range, frequencies, and percentages were calculated. In addition, asymmetry was calculated to verify the uniform distribution around the arithmetic mean. The kurtosis was used to verify the degree of concentration presented by the values in the central region of the distribution for each item. For construct validity, the multivariate analysis technique (confirmatory factorial analysis) was used. The calculation of the adjustment model provided values for the following: Varimax Kaiser-Meier-Olkin (KMO) rotation, $X^{2}$, square root of the residual mean (RMR), approximation (RMSEA), average mean square error of approximation (RMSEA), and percentage of variance.

The reliability of the instrument was verified by means of Cronbach's a. Percentile norms were created by using the LMS method (Cole et al., 2000). This technique allowed for the creation of three smoothed curves: L(t) Box-Cox Power, $M(t)$ Median, and $S(t)$ Coefficient of Variation. Percentiles p10, p50, and p90 were developed based on age and sex. All calculations were carried out on Excel sheets and with SPSS 18.0. The level of significance adopted was $p<$ .001 .

\section{Results}

The descriptive values obtained from the analysis of the instrument are illustrated in Table 1. Asymmetry showed values less than the average (-1.06 to - .11) while for the Kurtosis, values oscillated between .7 and .05 in all of the questions. Additionally, the factorial load values were confirmed for each category. Values varied between .32 and .54. The Kaiser-Meyer-Olkin KMO's measure of sampling adequacy obtained was .6804 . The chi-square relationship/ degrees of freedom was $X^{2} / d f=2.82(p=.000)$ and RMSEA (.058). The reliability values of a showed .83 to .84 . Following the confirmatory analysis, two questions ( 6 and 12) were eliminated due to the fact that they reflected values less than .29. As a result, the instrument consisted of 16 questions with a percentage of explication of $65.1 \%$ of the variance. 
Table 1. Descriptive analysis (average and $\pm S D$ ), saturation values, and Cronbach's a of the instrument.

\begin{tabular}{|c|c|c|c|c|c|}
\hline & Questions/categories & Asymmetry & Kurtosis & CF & Cronbach's a \\
\hline \multicolumn{6}{|c|}{ Knowledge transfer $(\%$ variance $=10.6 \%)$} \\
\hline 1 & I use what I learned in course subjects at school in situations in daily life. & -.754 & .697 & .41 & .84 \\
\hline 2 & Whenever possible, I use what I learned in one course in others. & -1.066 & .279 & .48 & .84 \\
\hline \multicolumn{6}{|c|}{ Personal knowledge as learning $(\%$ variance $=14.4 \%)$} \\
\hline 3 & $\begin{array}{l}\text { I know my personal strengths and weaknesses when undertaking learning in } \\
\text { course subjects. }\end{array}$ & -.584 & .677 & .54 & .83 \\
\hline 4 & $\begin{array}{l}\text { I am aware of when I do well on assignments in school without the need to } \\
\text { wait for the grades from the teacher. }\end{array}$ & -.456 & .741 & .39 & .84 \\
\hline 5 & When I have taken a test, I know whether I have done well or not. & -.414 & .326 & .40 & .84 \\
\hline \multicolumn{6}{|c|}{ Knowledge construction (\% variance $=12.5 \%)$} \\
\hline 6 & I know where I might find the materials necessary to study for course subjects. & -.116 & .209 & .48 & .84 \\
\hline 7 & I am able to select the necessary information to study subjects with success. & -.157 & .521 & .32 & .84 \\
\hline 8 & $\begin{array}{l}\text { I am capable of separating fundamental information necessary for preparing } \\
\text { course subjects from non-essential information. }\end{array}$ & -.376 & .323 & .40 & .84 \\
\hline 9 & $\begin{array}{l}\text { When I search on the Internet, I am capable of selecting the documents neces- } \\
\text { sary for the subjects I am working on or studying. }\end{array}$ & -.176 & .203 & .36 & .84 \\
\hline \multicolumn{6}{|c|}{ Self-directed learning $(\%$ variance $=\mathbf{2 7 . 6} \%)$} \\
\hline 10 & I persevere until I achieve the objectives I have set for myself. & -.408 & .247 & .33 & .83 \\
\hline & I continue my efforts in activities that are difficult or of little interest to me. & -.718 & .554 & .41 & .83 \\
\hline 12 & I take charge of my own learning. & -.283 & .357 & .41 & .84 \\
\hline 13 & I alter my learning strategies if they do not provide the results I expect. & .416 & .697 & .36 & .85 \\
\hline 14 & I am interested in learning from different situations. & -.447 & .257 & .42 & .83 \\
\hline 15 & I achieve a deep understanding of the themes that I learn. & -.395 & .049 & .46 & .83 \\
\hline 16 & I demonstrate skills to learn by myself. & .105 & .458 & .43 & .84 \\
\hline
\end{tabular}

Legend: $X=$ Average, $S D=$ Standard deviation, $C F=$ Factor load, $a=$ Cronbach's Alpha.

Table 2. Percentile values for assessing the skill levels for learning knowledge in adolescent students by age and sex.

\begin{tabular}{|c|c|c|c|c|c|c|c|c|c|c|c|c|c|c|}
\hline \multirow{2}{*}{$\begin{array}{c}\text { Age } \\
\text { (years) }\end{array}$} & \multirow[t]{2}{*}{ N } & \multicolumn{6}{|c|}{ Males $(n=1134)$} & \multirow[t]{2}{*}{$n$} & \multicolumn{6}{|c|}{ Females $(n=1136)$} \\
\hline & & L & M & $\mathrm{s}$ & p10 & p50 & p90 & & L & M & S & p10 & p50 & p90 \\
\hline \multicolumn{15}{|c|}{ Knowledge transfer (KT) } \\
\hline 10 & 68 & 1.82 & 4.64 & .21 & 3.2 & 4.6 & 5.8 & 76 & 1.28 & 4.68 & .21 & 3.4 & 4.7 & 5.9 \\
\hline 11 & 124 & 1.63 & 4.56 & .21 & 3.2 & 4.6 & 5.7 & 121 & 1.33 & 4.60 & .21 & 3.3 & 4.6 & 5.8 \\
\hline 12 & 165 & 1.43 & 4.50 & .21 & 3.2 & 4.5 & 5.6 & 196 & 1.35 & 4.50 & .21 & 3.2 & 4.5 & 5.7 \\
\hline 13 & 161 & 1.24 & 4.43 & .21 & 3.2 & 4.4 & 5.6 & 185 & 1.30 & 4.40 & .21 & 3.2 & 4.4 & .5 \\
\hline 14 & 173 & 1.06 & 4.38 & .20 & 3.2 & 4.4 & 5.5 & 156 & 1.06 & 4.41 & .20 & 3.3 & 4.4 & 5.5 \\
\hline 15 & 184 & .88 & 4.35 & .20 & 3.2 & 4.3 & 5.5 & 135 & .58 & 4.41 & .19 & 3.4 & 4.4 & 5.5 \\
\hline 16 & 134 & .69 & 4.38 & .20 & 3.3 & 4.4 & 5.5 & 115 & -.03 & 4.38 & .17 & 3.5 & 4.4 & 5.5 \\
\hline 17 & 66 & .56 & 4.37 & .19 & 3.3 & 4.4 & 5.5 & 85 & -.66 & 4.36 & .16 & 3.6 & 4.4 & 5.4 \\
\hline 18 & 59 & .48 & 4.33 & .19 & 3.3 & 4.3 & 5.5 & 67 & -1.30 & 4.38 & .14 & 3.7 & 4.4 & 5.4 \\
\hline \multicolumn{15}{|c|}{ Personal knowledge as learning (PCL) } \\
\hline 10 & 68 & 1.50 & 6.73 & .18 & 5.1 & 6.7 & 8.2 & 76 & 1.63 & 6.90 & .18 & 5.1 & 6.9 & 8.4 \\
\hline 11 & 124 & 1.46 & 6.75 & .18 & 5.1 & 6.8 & 8.2 & 121 & 1.60 & 6.89 & .18 & 5.2 & 6.9 & 8.4 \\
\hline 12 & 165 & 1.41 & 6.84 & .18 & 5.2 & 6.8 & 8.3 & 196 & 1.55 & 6.89 & .18 & 5.2 & 6.9 & 8.4 \\
\hline 13 & 161 & 1.35 & 6.85 & .18 & 5.2 & 6.8 & 8.3 & 185 & 1.46 & 6.96 & .17 & 5.3 & 7.0 & 8.4 \\
\hline 14 & 173 & 1.34 & 6.82 & .18 & 5.2 & 6.8 & 8.3 & 156 & 1.37 & 7.00 & .17 & 5.4 & 7.0 & 8.5 \\
\hline 15 & 184 & 1.41 & 6.89 & .18 & 5.2 & 6.9 & 8.4 & 135 & 1.31 & 7.06 & .16 & 5.5 & 7.1 & 8.5 \\
\hline 16 & 134 & 1.52 & 7.04 & .18 & 5.3 & 7.0 & 8.6 & 115 & 1.29 & 7.09 & .16 & 5.6 & 7.1 & 8.5 \\
\hline 17 & 66 & 1.69 & 7.09 & .18 & 5.3 & 7.1 & 8.6 & 85 & 1.31 & 7.17 & .15 & 5.8 & 7.2 & 8.5 \\
\hline 18 & 59 & 1.90 & 7.05 & .18 & 5.2 & 7.1 & 8.6 & 67 & 1.32 & 7.16 & .14 & 5.8 & 7.2 & 8.4 \\
\hline
\end{tabular}




\begin{tabular}{|c|c|c|c|c|c|c|c|c|c|c|c|c|c|c|}
\hline \multirow{2}{*}{$\begin{array}{c}\text { Age } \\
\text { (years) }\end{array}$} & \multirow[t]{2}{*}{$N$} & \multicolumn{6}{|c|}{ Males $(n=1134)$} & \multirow[t]{2}{*}{$n$} & \multicolumn{6}{|c|}{ Females $(n=1136)$} \\
\hline & & $\mathrm{L}$ & M & $\mathrm{S}$ & p10 & p50 & p90 & & $\mathrm{L}$ & M & $\mathrm{S}$ & p10 & p50 & p90 \\
\hline \multicolumn{15}{|c|}{ Knowledge construction (KC) } \\
\hline 10 & 68 & 2.16 & 9.93 & .16 & 7.6 & 9.9 & 11.7 & 76 & 2.17 & 9.77 & .15 & 7.6 & 9.8 & 11.5 \\
\hline 11 & 124 & 2.11 & 9.83 & .16 & 7.6 & 9.8 & 11.6 & 121 & 2.12 & 9.84 & .15 & 7.7 & 9.8 & 11.6 \\
\hline 12 & 165 & 2.08 & 9.79 & .16 & 7.6 & 9.8 & 11.6 & 196 & 2.08 & 9.89 & .15 & 7.7 & 9.9 & 11.6 \\
\hline 13 & 161 & 2.07 & 9.71 & .16 & 7.5 & 9.7 & 11.5 & 185 & 2.07 & 9.92 & .15 & 7.8 & 9.9 & 11.7 \\
\hline 14 & 173 & 2.06 & 9.67 & .16 & 7.5 & 9.7 & 11.4 & 156 & 2.09 & 9.99 & .15 & 7.8 & 10.0 & 11.7 \\
\hline 15 & 184 & 2.03 & 9.71 & .16 & 7.5 & 9.7 & 11.5 & 135 & 2.10 & 10.02 & .15 & 7.8 & 10.0 & 11.8 \\
\hline 16 & 134 & 1.99 & 9.76 & .16 & 7.5 & 9.8 & 11.6 & 115 & 2.09 & 10.02 & .15 & 7.8 & 10.0 & 11.8 \\
\hline 17 & 66 & 1.97 & 9.73 & .16 & 7.5 & 9.7 & 11.6 & 85 & 2.05 & 10.11 & .15 & 7.9 & 10.1 & 11.9 \\
\hline 18 & 59 & 1.96 & 9.55 & .17 & 7.3 & 9.5 & 11.4 & 67 & 2.01 & 10.24 & .15 & 8.0 & 10.2 & 12.1 \\
\hline \multicolumn{15}{|c|}{ Self-directed of learning (SDL) } \\
\hline 10 & 68 & 0.99 & 16.80 & .17 & 12.0 & 17.0 & 20.0 & 76 & 1.11 & 15.96 & .18 & 12.2 & 16.0 & 20.7 \\
\hline 11 & 124 & 1.11 & 15.80 & .15 & 12.0 & 16.0 & 20.0 & 121 & 1.29 & 16.20 & .17 & 12.4 & 16.2 & 20.7 \\
\hline 12 & 165 & 1.44 & 15.90 & .15 & 12.0 & 16.0 & 20.0 & 196 & 1.49 & 16.15 & .17 & 12.5 & 16.1 & 20.5 \\
\hline 13 & 161 & 1.54 & 15.70 & .15 & 12.0 & 16.0 & 20.2 & 185 & 1.62 & 16.08 & .16 & 12.5 & 16.1 & 20.2 \\
\hline 14 & 173 & 1.57 & 15.80 & .14 & 12.0 & 16.0 & 20.0 & 156 & 1.61 & 16.22 & .15 & 12.8 & 16.2 & 20.3 \\
\hline 15 & 184 & 1.44 & 14.80 & .14 & 12.0 & 15.0 & 20.0 & 135 & 1.49 & 16.21 & .15 & 12.8 & 16.2 & 20.2 \\
\hline 16 & 134 & 1.21 & 15.80 & .14 & 12.0 & 16.0 & 20.0 & 115 & 1.33 & 16.10 & .15 & 12.8 & 16.1 & 20.0 \\
\hline 17 & 66 & 1.08 & 16.80 & .11 & 12.0 & 17.0 & 20.0 & 85 & 1.18 & 16.04 & .14 & 12.0 & 16.0 & 20.0 \\
\hline 18 & 59 & 0.98 & 15.40 & .13 & 12.6 & 15.5 & 20.1 & 67 & 1.07 & 15.80 & .14 & 12.9 & 15.8 & 20.2 \\
\hline \multicolumn{15}{|c|}{ Level of skill for learning(Full scale) } \\
\hline 10 & 68 & 1.47 & 42.80 & .13 & 30.9 & 43.0 & 48.9 & 76 & 1.51 & 41.90 & .15 & 33.4 & 41.9 & 49.6 \\
\hline 11 & 124 & 1.68 & 39.80 & .12 & 33.0 & 40.0 & 47.3 & 121 & 1.78 & 41.95 & .15 & 33.5 & 41.9 & 49.2 \\
\hline 12 & 165 & 1.98 & 41.90 & .11 & 35.0 & 42.0 & 50.0 & 196 & 2.00 & 41.70 & .14 & 33.3 & 41.7 & 48.7 \\
\hline 13 & 161 & 1.99 & 39.80 & .11 & 34.0 & 40.0 & 47.0 & 185 & 2.03 & 41.50 & .14 & 33.3 & 41.5 & 48.3 \\
\hline 14 & 173 & 1.65 & 40.70 & .13 & 34.0 & 41.0 & 48.0 & 156 & 1.70 & 41.81 & .14 & 34.0 & 41.8 & 48.7 \\
\hline 15 & 184 & 1.14 & 39.80 & .13 & 31.0 & 40.0 & 47.0 & 135 & 1.25 & 42.07 & .13 & 33.0 & 42.1 & 49.1 \\
\hline 16 & 134 & .86 & 40.80 & .11 & 35.0 & 41.0 & 48.0 & 115 & 0.91 & 41.98 & .13 & 35.1 & 42.0 & 49.0 \\
\hline 17 & 66 & .68 & 42.80 & .11 & 34.5 & 43.0 & 49.5 & 85 & 0.74 & 41.85 & .13 & 35.3 & 41.8 & 48.7 \\
\hline 18 & 59 & .61 & 40.10 & .98 & 32.5 & 40.5 & 47.2 & 67 & 0.68 & 41.31 & .12 & 35.0 & 41.3 & 47.9 \\
\hline $\mathrm{T}$ & 1134 & 1.34 & 40.94 & 0.21 & 33.3 & 41.2 & 48.1 & 1136 & 1.40 & 41.79 & 0.1 & 33.9 & 41.7 & 48.870 \\
\hline
\end{tabular}

Legend: L: Asymmetry, M: Median, S: Coefficient of variation, KC: Knowledge transfer, PCL: Personal knowledge as learning, KC: Knowledge construction, SDL: Self-directed learning.

Table 2 depicts the percentiles that may be used to diagnose the SLACK. The p50 values for both sexes showed relatively similar values, and they remained relatively stable with regard to age. Furthermore, the competency levels may be evaluated by category, age, sex, and the entire scale.
Figure 2 illustrates the cut-off points for evaluating the SLACK in adolescents of both sexes. These values coincided for both sexes. Therefore, only one scale has been created for both sexes. These values may be interpreted as low level, moderate level, and high level.

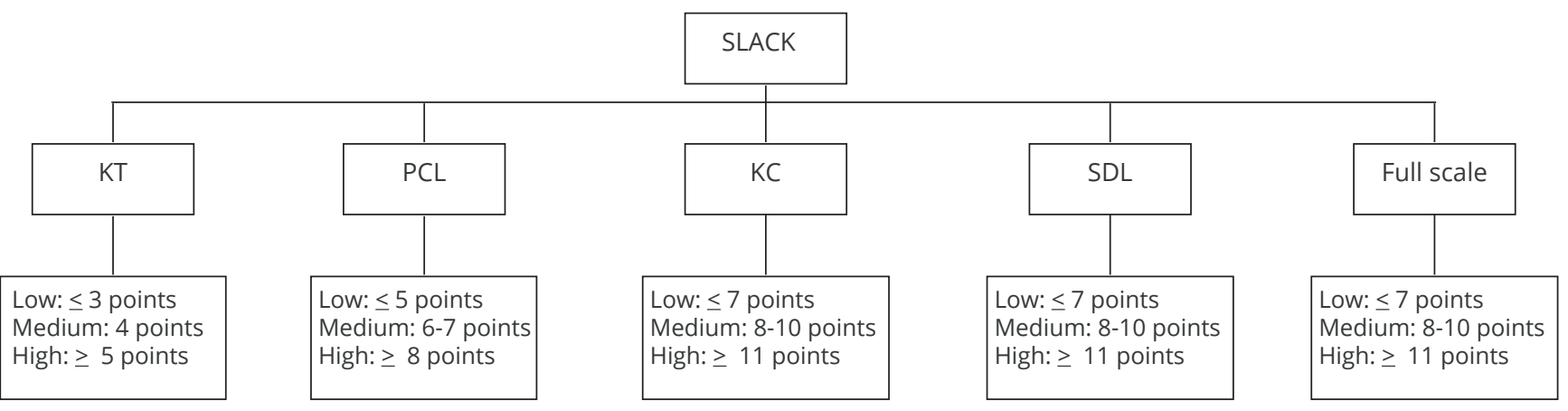

Figure 2. Cut-off points for assessing skill levels for learning knowledge SLACK in adolescent students of both sexes (KT: Knowledge transfer, PCL: Personal knowledge as learning, KC: Knowledge construction, SML: Self-directed learning). 


\section{Discussion}

With regard to the validity of the scale used to assess the adolescent students of the Maule Region, the results of the study showed that the instrument is valid. This was verified through confirmatory factorial analysis. The factorial loads showed values greater than .32. In fact, the values obtained are considered to be the acceptable minimums since factorial loads between .50 and .70 are significant, and factorial loads greater than .70 are indicators of well-defined saturation (Figueiredo-Filho \& Silva-Junior, 2010). Furthermore, it is necessary to point out that the KMO (.6804) values obtained in this study are considered reasonable since they are in the range of .60 to .70 (Dini et al., 2014). The RMSEA index showed a value less than 0.05 . In the model, this reflects a good fit (Browne \& Cudeck, 1993).

In general, the instrument validated showed values inferior to the values of the original study of the scale (Villardón-Gallego et al., 2013). However, these values are similar in relation to studies that sought to validate scales through confirmatory analysis (Iglesias, 2009; Jaramillo \& Ossesa, 2012; Caso-López, Niebla, Fierro-Evans, \& Díaz-López, 2015). Moreover, the percentage of the explication of the variance of the instrument as a whole showed $65.1 \%$. This guarantees the power of the explanation of the instrument even though the original scale showed much higher values in relation to this research study.

It is necessary to highlight that after the two AFC questions were eliminated, these reflected factorial loads less than 0.29 . Thus, the original instrument was reduced to 16 questions. These allowed confirmation of the parameters of the model initially proposed.

With regard to the reliability of the instrument, Cronbach's a values were highly reliable (.83 to .84). These findings are consistent with other studies with similar objectives (Jaramillo \& Ossesa, 2012; Cossio-Bolaños, Monné, Cornejo, Lepe, Vidal, \& Araújo, 2013; Dini, Alves, Oliveira, \& Guirardello, 2014). In terms of quality control, reliability is a necessary requirement that needs to be performed after the validation process. Therefore, the values observed in this study are considered to be acceptable based on the descriptive suggestions provided by Oviedo and Campos (2005). Furthermore, it is necessary to emphasize that Cronbach's a, without a doubt, is the technique most commonly used by researchers, especially when it means saving time and costs and surveying large populations at a given time (Gómez-Campos et al., 2015).

To construct the cut-off points and to classify the adolescents according to the skill levels, the creation of percentiles was opted for. These were calculated by using the LMS method (Cole, Bellizzi, Flegal, \& Dietz, 2000) where the extremes of the centiles may be estimated more efficiently and precisely in relation to traditional methods (Kulaga et al., 2011).

Therefore, the percentile for an individual indicates the NCPAC whether it is by category or by the entire scale. This tool serves to classify and diagnose (Conde \& Monteiro, 2006) reference groups and/or to separate subjects with a greater competency level in relation to those with lower levels. Thus, validation of the skills for learning may be estimated by using self-directed, knowledge construction, personal knowledge as learning, and knowledge transfer. These competencies involve processes such as evaluating specific learning needs selection of specific strategies, and monitoring learning until objectives pursued are acquired (Schulz \& Stamov, 2010).

Actually, adolescents and children need a wide range of skills for their future personal and professional development (Gordon et al., 2009). Therefore, in a globalized, diverse, and constantly changing society, it is necessary to develop new strategies for learning knowledge. For this, it is necessary to stimulate from infancy until adulthood formal and non-formal education environments (Comisión de las Comunidades Europeas, 1999). Thus, permanent learning should be considered as a priority for educational policies of a region and/ or country as is proposed for the European Union (Valle \& Manso, 2013) where education is conceived as lifelong learning, and its development should be throughout the lifetime. Therefore, this might guarantee better performance for adolescents in the future, especially during the school years, university life, and professional practice.

In general, this study has some potential advantages based on the large sample size, the probabilistic selection of the sample, and the validity of the instrument used to carry out this research. These guarantee generalizability of the results to the Maule Region, including the sample of adolescents throughout Chile. However, on the other hand, it is necessary to point out that it was not possible to establish reliability based on measures of stability (test re-test). This would have guaranteed better quality control of the scale used. Future studies should control for this elementary aspect even though it would mean a greater inversion of time and money. Another aspect that could not be controlled for was socio-economic status since this study was limited to studying students in state schools (called municipal in Chile).

\section{Conclusion}

In conclusion, based on the results obtained from this study, the researchers concluded that the scale for assessing the skill levels for learning knowledge SLACK in statistical terms were valid and reliable. The results suggest the use and implementation of this instrument within the educational system, particularly in Chile. Percentiles are available for diagnosing, classifying, and monitoring skills for learning knowledge during adolescence. The calculations for the scale may be carried out in real time using the following link: http://www.reidebihu.net/learn_knowledge.php. To confirm these findings, more research studies are necessary. These need to include students from different economic backgrounds, geographic regions, and urban and rural areas, respectively.

\section{Acknowledgements}

The authors wish to thank the teachers and students of the participating schools and the PMI, of the Faculty of Education, Universidad Católica del Maule.

\section{Disclosure statement}

The authors reported no potential conflict of interest.

\section{References}

Browne, M.W. \& Cudeck, R. (1993). Alternative ways of assessing model fit. In: K. A. Bollen \& J. S. Long (Eds.), Testing structural equation models. Beverly Hills, CA: Sage.

Cabanach, R., Valle, A., Gerpe, M., Rodríguez, S., Piñeiro, I. \& Rosario, P. (2006). Diseño y validación de un cuestionario de gestión motivacional. Revista de Psicodidáctica, 14(1), 29-47. https://www.redalyc.org/ pdf/175/17512723003.pdf

Caso-López, A., Niebla, J., Fierro Evans, MC. \& Díaz López, C. (2015). Desarrollo de un instrumento de evaluación basado en indicadores de convivencia escolar democrática, inclusiva y pacífica. Perfiles Educativos, 37(149), 20-41. http:// www.scielo.org.mx/scielo.php?script=sci_arttext\&pid=S0185-26982015000300002

Comisión de las Comunidades Europeas (1999). Implementation, Results and Overall Assessment of the European 
Year of Lifelong Learning. Luxemburgo: Office for Official Publications of the European Communities.

Cole, TJ., Bellizzi, MC., Flegal, KM. \& Dietz, WH. (2000). Establishing a standard definition for child overweight and obesity worldwide: international survey. BMJ, 320(7244),1240-3. https://www.ncbi.nlm. nih.gov/pubmed/10797032

CCE Comisión de las Comunidades Europeas (2005). Recomendación del Parlamento y del Consejo sobre las competencias clave del aprendizaje permanente. Brussels. Recuperado de http://www. crue.org/export/sites/Crue/procbolonia/documentos/antecedentes/9.Competencias_clave para_aprendizaje_permanente.pdf. Accessed: $07 / 0 \overline{3} / 2011$

Conde, W. \& Monteiro, CA. (2006). Body mass index cutoff points for evaluation of nutritional status in Brazilian children and adolescents. J Pediatr (Rio J), 82(4), 266-272. doi:10.2223/JPED.1502

Cossio-Bolaños, MA., Monné, R., Cornejo, C., Lepe, N., Vidal, R. \& Araújo, P. (2013). Construcción de un instrumento para medir el uso del conocimiento científico en alumnos de educación especial y psicopedagogía. Multiciencias, 13(1), 68-74.

Dini, A., Alves, DF., Oliveira, H. \& Guirardello, E. (2014). Validez y confiabilidad de un instrumento de clasificación de pacientes pediátricos. Rev. Latino-Am. Enfermagem, 22(4), 598-603. DOI: 10.1590/01041169.3575 .2457

European Commission (2001). Making a European area of lifelong learning a reality. Brussels. Retrieved from http://www.bologna-berlin2003.de/pdf/ MitteilungEng.pdf

Figueiredo-Filho, DB. \& Silva-Junior, JÁ. (2010). Visão além do alcance: uma introdução à análise fatorial. Opin Pública, 16(1), 160-85. DOI.org/10.1590/S010462762010000100007

Gómez-Campos, R., Arruda, M., Sulla, J., Alvear, F., Urra, C., González, C., Luarte, C. \& Cossio-Bolaños, M. (2015). Construcción de un instrumento para valorar la actitud a la obesidad en adolescentes. Rev Chil Nutr, 42(3), 277-283.

Gordon, J., Halasz, G., Krawczyk, M., Leney, T., Michel, A., Pepper, D. Putkiewicz, E. \& Winiewski, J. (2009). Key Competences in Europe: Opening Doors for Lifelong Learners across the School Curriculum and Teacher Education. Varsovia: CASE.

Hair, JF., Anderson, RE., Tatham, RL. \& Black, WC. (2009). Análise multivariada de dados. ${ }^{\mathrm{a}}$. ed. Porto Alegre: Bookman, 688p

Iglesias, MJ. (2009). Elaboración y validación de un instrumento diagnóstico para la percepción de las competencias emocionales en estudiantes universitarios de educación. REOP, 20(3), 300-311.

IVEIE Instituto Vasco de evaluación e investigación educativa. (2012). Competencia para aprender a aprender. Gobierno Vasco.

Jaramillo, S. \& Ossesa, S. (2012). Validación de un Instrumento sobre Metacognición para Estudiantes de Segundo Ciclo de Educación General Básica. Es- tudios Pedagógicos, 38(2), 117-131. http://dx.doi. org/10.4067/S0718-07052012000200008

Kulaga Z., Litwin, M., Tkaczyk, M., Palczewska, I., Zaja,czkowska, M., Zwolinska, D., Krynicki, T., Wasilewska, A., Moczulska, A., Moraw-iec-Knysak, A., Barwicka, K., Grajda, A., Gurzkowska, B., Napieral-ska, E. \& Pan, H. (2011). Polish 2010 growth references for school-aged children and adolescents. Eur J Pediatr, 170, 599-609. 10.1007/s00431-010-1329-x

Oviedo, C. \& Campo-Arias, A. (2005). Aproximación al uso del coeficiente alfa de Cronbach. Rev Colomb Psiquiatr, 34, 572-80.

Ríos-Ariza, JM. \& Gómez Barajas, ER. (2013). Relación entre competencias básicas de los estudiantes y competencias del profesorado. Revista Fuentes, 14, 209230

Sáiz, M.C., Montero, E., Bol, A. \& Carbonero, M.A. (2012). Un análisis de competencias para aprender a aprender en la universidad. Electroni Journal of Research in Educational Psychology, 10(1), 253-270. Retrieves from http://www.investigacionpsicopedagogica. org/revista/new/ContadorArticulo.php?629.

Salmerón, H. \& Gutiérrez, C. (2012). La competencia para aprender a aprender y el aprendizaje autorregulado. Posicionamientos Teóricos. Revista de Currículum y Formación del Profesorado, 16(1), 5-13. Recuperado de http://www.ugr.es/ recfpro/rev161ART1.pdf

Suárez, J.M. \& Fernández, A.P. (2011). Evaluación de las estrategias de autorregulación afectivomotivacional de los estudiantes: Las EEMA-VS. Anales de Psicología, 27(2), 369-380.

Schulz, M. \& Stamov, C. (2010). Informal workplace learning: An exploration of age differences in learning competence. Learning and Instruction, 20(5), 383399.

Valle, J., Manso, J. (2013). Competencias clave como tendencia de la política educativa supranacional de la Unión Europea. Revista de Educación, Extraordinario: $12-33$

Villardón-Gallego, L., Yániz, C., Achurra, C., Iraurgi, I. \& Aguilar, M.C. (2013). Learning Competence in University: Development and Structural Validation of a Scale to Measure. Revista de Psicodidáctica, 18(2), 357-374

Zimmerman, B. (1989). A social-cognitive view of self-regulated academic learning. Journal of Educational Psychology, 81, 329-339. 